\title{
Uptake and Release of Aroma Compounds by an Ethylene Propylene Diene Monomer Rubber Sealing Polymer: Investigating Aroma Carryover in a Model Wine System
}

Jörg Gottmann ${ }^{1,2}$, Jochen Vestner ${ }^{1}$, David Müller ${ }^{3}$, Jens Schuster ${ }^{3}$, Ulrich Fischer ${ }^{1,2 *}$

${ }^{1}$ Dienstleistungszentrum Ländlicher Raum (DLR) Rheinpfalz, Institute for Viticulture and Oenology, Breitenweg 71, 67435 Neustadt an der Weinstraße, Germany

${ }^{2}$ Kaiserslautern University of Technology, Department of Chemistry, Erwin-Schrödinger-Straße 52, 67663 Kaiserslautern, Germany

${ }^{3}$ Kaiserslautern University of Applied Sciences, Institut für Kunststofftechnik Westpfalz (IKW), CarlSchurz-Str. 10-16, 66953 Pirmasens, Germany

* Corresponding author

phone: +496321671294

fax: +496321671375

e-mail: ulrich.fischer@dlr.rlp.de

\section{ORCID}

Jörg Gottmann: 0000-0003-3542-8843

Jochen Vestner: 0000-0003-2648-4325

Ulrich Fischer: 0000-0003-1566-8516 


\section{SUPPORTING INFORMATION}

\section{FIGURES CAPTIONS}

Figure S1. Developed model system to investigate installed sealings inside pipes of a filling line towards the absorption and migration process of aroma compounds, EPDM disks (4) are clamped into the stainless-steel bracket (1-3). The clamping device is stored in a vessel (5).

Figure S2. Total ion current (TIC) for a desorption temperature of 90,150 and $200{ }^{\circ} \mathrm{C}$ obtained for direct thermal desorption analysis (TD-GC-MS) of EPDM samples. Higher temperature leads to increased background noise. At the end of the TD-GC-MS run with a desorption temperature of $200{ }^{\circ} \mathrm{C}$ a high increased baseline is seen. Therefore, a strong contamination of the analysis system is present at the end of each measurement. 

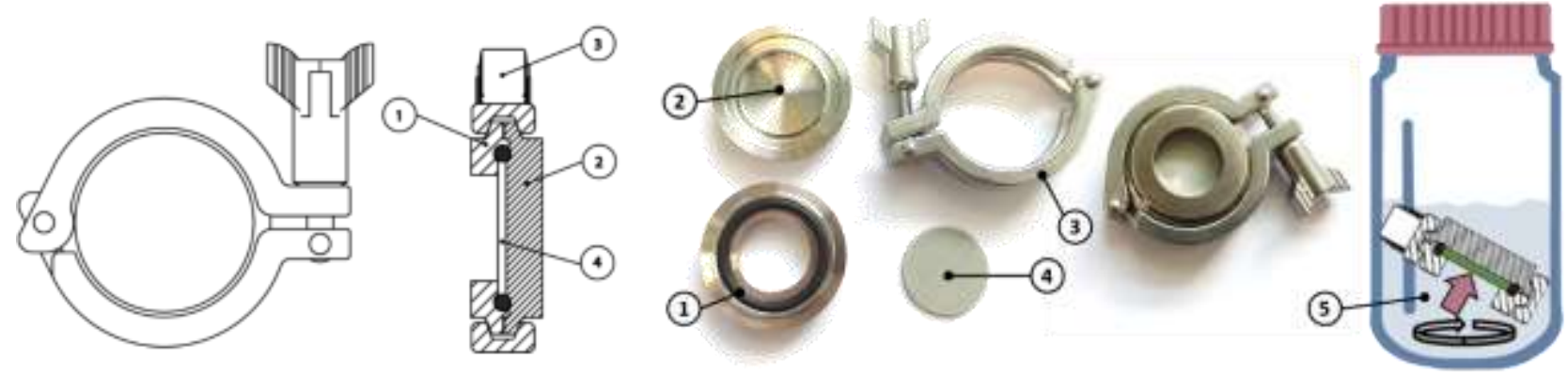

Figure S1 


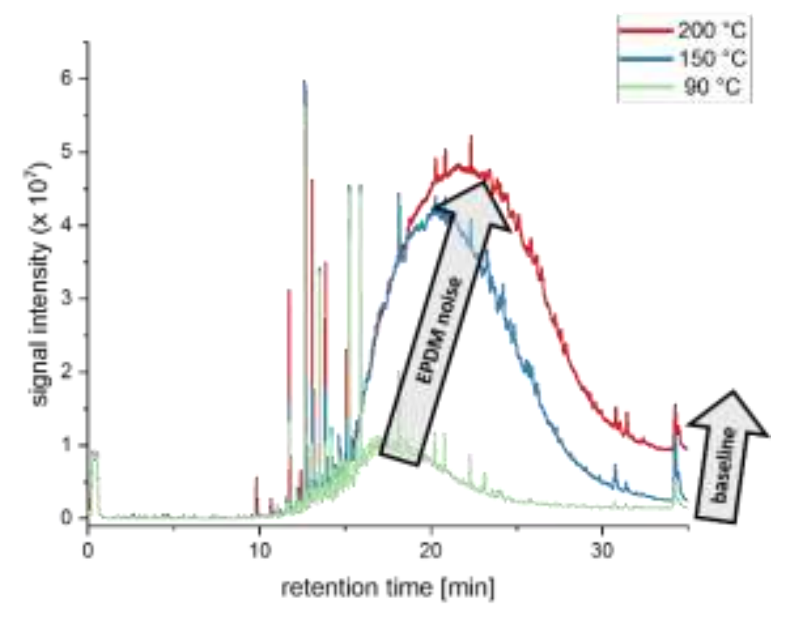

Figure S2 
Table S1. Calculated physical properties for selected aroma compounds by archemcalc.com/sparc and ACD/Labs Software V11.02.

\begin{tabular}{|c|c|c|c|c|c|c|c|c|}
\hline & $\begin{array}{l}\text { molecular } \\
\text { weight } \\
\text { [g/mol] }\end{array}$ & $\begin{array}{l}\text { boilingpoint } \\
{\left[{ }^{\circ} \mathrm{C}\right]}\end{array}$ & $\begin{array}{l}\text { diffusion } \\
\text { in Air } \\
{\left[\mathrm{cm}^{2} / \mathrm{s}\right]}\end{array}$ & $\begin{array}{l}\text { diffusion } \\
\text { in Water } \\
{\left[\mathrm{cm}^{2} / \mathrm{s}\right]}\end{array}$ & $\begin{array}{l}\text { Henry's } \\
\text { Constant } \\
(\log \mathrm{H})\end{array}$ & $\begin{array}{l}\text { distribution } \\
\text { octanol/water } \\
(\log P)\end{array}$ & $\begin{array}{l}\text { vapor } \\
\text { pressure } \\
{[\mathrm{Pa}]}\end{array}$ & $\mathrm{LRI}^{\mathrm{a}}$ \\
\hline $\begin{array}{l}\text { ethyl 2- } \\
\text { methylbutanoate }\end{array}$ & 130 & 133 & 0.062 & 7.19E-06 & -1.45 & 2.15 & 1240 & 1052 \\
\hline$\alpha$-ionone & 192 & 237 & 0.045 & $5.84 \mathrm{E}-06$ & -2.81 & 3.66 & 2.2 & 1859 \\
\hline eugenol & 164 & 253 & 0.055 & 7.07E-06 & -3.69 & 2.4 & 0.72 & 2179 \\
\hline $\begin{array}{l}\text { trans- } \\
\text { cinnamaldehyde }\end{array}$ & 132 & 246 & 0.063 & 7.93E-06 & -3.84 & 1.9 & 10.17 & 2139 \\
\hline$\gamma$-decalactone & 170 & 281 & 0.048 & $6.43 \mathrm{E}-06$ & -4.36 & 2.45 & 1.49 & 2158 \\
\hline$\delta$-decalactone & 170 & 267 & 0.048 & $6.48 \mathrm{E}-06$ & -4.52 & 2.46 & 1.13 & 2204 \\
\hline$\gamma$-undecalactone & 184 & 286 & 0.045 & $6.10 \mathrm{E}-06$ & -4.27 & 2.96 & 0.51 & 2274 \\
\hline
\end{tabular}

${ }^{a}$ Linear Retention Index (LRI) experimentally calculated for ZB-WAX 